\title{
Dairy system, parity, and lactation stage affect enteric methane production, yield, and intensity per kilogram of milk and cheese predicted from gas chromatography fatty acids
}

\author{
Giovanni Bittante, Alessio Cecchinato, ${ }^{1}$ and Stefano Schiavon \\ Department of Agronomy, Food, Natural Resources, Animals and Environment (DAFNAE), University of Padova, Viale dell'Università 16, \\ 35020 Legnaro, Padova, Italy
}

\begin{abstract}
Ruminants (and milk production) contribute to global climate change through enteric methane emissions (EME), and any attempt to reduce them is complicated by the fact that they are difficult and expensive to measure directly. In the case of dairy cows, a promising indirect method of estimating EME is to use the milk fatty acid profile as a proxy, as a relationship exists between microbial activity in the rumen and the molecules available for milk synthesis in the mammary gland. In the present study, we analyzed the detailed fatty acid profiles (through gas chromatography) of a large number of milk samples from 1,158 Brown Swiss cows reared on 85 farms with the aim of testing in the field 2 equations for estimating EME taken from a published meta-analysis. The average estimated methane yield $\left(\mathrm{CH}_{4}\right.$ emission per $\mathrm{kg}$ of dry matter intake, $21.34 \pm 1.60 \mathrm{~g} / \mathrm{kg}$ ) and methane intensity (per $\mathrm{kg}$ of corrected milk, $14.17 \pm 1.78 \mathrm{~g} / \mathrm{kg}$ ), and the derived methane production $\left(\mathrm{CH}_{4}\right.$ emissions per day per cow, $357 \pm 109 \mathrm{~g} / \mathrm{d}$ ) were similar to those previously published. Using data from model cheese makings from individual cows, we also calculated estimated methane intensity per kilogram of fresh cheese $(99.7 \pm 16.4 \mathrm{~g} /$ $\mathrm{kg})$ and cheese solids $(207.5 \pm 30.9 \mathrm{~g} / \mathrm{kg})$. Dairy system affected all EME estimates. Traditional dairy farms, and modern farms including corn silage in the TMR exhibited greater estimated methane intensities. We found very wide variability in estimated EME traits among different farms within dairy system (0.33 to 0.61 of total variance), suggesting the need to modify the farms' feeding regimens and management practices to mitigate emissions. Among the individual factors, parity order affected all estimated EME traits excepted methane yield, with an increase from first lactation to the following ones. Lactation stage exhibited more favorable estimated EME traits during early lactation,
\end{abstract}

Received July 10, 2017.

Accepted October 13, 2017.

${ }^{1}$ Corresponding author: alessio.cecchinato@unipd.it concomitant with the availability of nutrients from body tissue mobilization for mammary synthesis of milk. Our results showed a coherence between the EME traits estimated from the analysis of milk fatty acids and the expectations according to current knowledge. Further research is needed to validate the results obtained in this study in other breeds and populations, to assess the magnitude of the genetic variation and the potential of these phenotypes to be exploited in breeding programs with the aim to mitigate emissions. Key words: dairy system, ecological footprint, greenhouse gas, global warming, cheese effect

\section{INTRODUCTION}

Ruminants are thought to be responsible for between 3 and $18 \%$ of global greenhouse gas (GHG) emissions (Pitesky et al., 2009; Knapp et al., 2014), a significant contribution to which is made by dairy cows. Feeding regimen, productivity, and manure management, and therefore dairy system, are considered the main sources of variation in the emission of enteric methane (EME), the most important GHG emitted by the dairy sector. Genetic variations among and within breeds also play a role in the amount of EME emitted by dairy cows (de Haas et al., 2011).

Direct quantification of GHG requires the facilities, tools, and knowledge normally available only in few research centers (Knapp et al., 2014), making it very difficult to directly test GHG emissions in the field with a large number of farms and cows. It is therefore essential to develop indirect methods of quantifying EME to compare different dairy systems at a practical level, and to acquire data from a wide range of individual cows as a basis for estimating breeding value for EME traits for the genetic improvement of dairy populations for these traits.

As recently reviewed by Negussie et al. (2017), many proxies have been proposed for large-scale indirect measurements of EME in dairy cattle for use in making management and breeding decisions. Of these, the analysis of milk fatty acid (FA) profiles and the use 
of proper combinations of FA are methods more easily used in the field, needing only the collection of milk samples and their analysis in the laboratory.

The underlying biological phenomenon is the production of $\mathrm{CH}_{4}$ in the rumen and other fore-stomachs of ruminants by rumen microbes from the $\mathrm{H}_{2}$ generated from carbohydrate fermentation to produce acetate and butyrate (Demeyer and van Nevel, 1975; Morvay et al., 2011). These 2 VFA are the main substrate of de novo synthesis of the even short- and mid-chain FA by the mammary gland of dairy cows (Chilliard et al., 2000) and consequently a direct relationship is present between EME and the de novo synthesis in the udder. Also, other milk FA are related to the rumen environment and microbiota activity, such as odd- and branched-chain FA, which are mainly produced by microbial activity (Castro Montoya et al., 2011), and long-chain UFA, which tend to depress microbial fermentation and EME in the rumen (Doreau and Ferlay, 1993).

Some interesting studies have been carried out in recent years using the gold standard for EME measurements, respiration chambers, and for FA profile analysis, GC (see the extensive review of van Gastelen and Dijkstra, 2016). These studies have focused on different sources of forage in feeds (Dehareng et al., 2012; Dijkstra et al., 2016; Rico et al., 2016), different oilseeds (Chilliard et al., 2009; Mohammed et al., 2011), and rumen-active supplements (Dijkstra et al., 2011). Being based on EME measurements in the respiration chambers, each one of these studies was carried out with small numbers of cows and few diets in strictly experimental conditions, so the results cannot be easily generalized to field conditions (Williams at al., 2014). On the other hand, van Lingen et al. (2014) undertook a meta-analysis of the relationships between EME and milk FA profiles by combining the data from 4 experiments carried out at the University of Reading (United Kingdom; Crompton et al., 2010, 2011; Reynolds et al., 2010, 2012), and 4 experiments carried out at Wageningen University (the Netherlands; van Zijderveld et al., 2011a,b; van Gastelen et al., 2014), covering 30 different diets. They devised 2 equations for predicting EME traits, one for methane yield $\left(\mathrm{CH}_{4}\right.$ per $\mathrm{kg}$ of DMI) and one for methane intensity $\left(\mathrm{CH}_{4}\right.$ per $\mathrm{kg}$ of fat- and protein-corrected milk, CM). Both have a good level of accuracy, considering that the data were obtained from different experiments, and with different diets and environmental conditions, even though lower than equations obtained from single studies in one location and few diets (Chilliard et al., 2009; Mohammed et al., 2011; Rico et al., 2016).

Few, if any, studies have applied these equations obtained from meta-analysis of large-scale data sets from field surveys to predict EME, and little information is available on the cheese-making ability of different cows as a basis for calculating EME per kilogram of cheese produced.

In this study, we applied the van Lingen et al. (2014) equations to a set of data from a large-scale field survey to quantify the EME traits predicted by selected milk FA and to assess their main sources of variation. The specific aims were (1) to estimate methane yield (per $\mathrm{kg}$ of DMI), methane intensity (per $\mathrm{kg}$ of milk and per $\mathrm{kg}$ of cheese), and daily methane production of individual cows; (2) to compare different dairy systems; (3) to quantify the variations in the estimated EME traits among different herds reared in the same dairy system; and (4) to analyze the effect of parity and lactation stage of individual cows on the estimated EME traits.

\section{MATERIALS AND METHODS}

\section{Dairy Farming Systems and Herds}

This study is part of the Cowability-Cowplus projects. Briefly, we carried out the study on 85 herds located in Trento Province (northeastern Italian Alps) and registered with the milk-recording program of the local Provincial Breeders' Federation (Federazione Provinciale Allevatori, Trento, Italy). The herds were selected from 610 farms to represent different environments and dairy farming systems (Sturaro et al., 2013).

Briefly, 29 of the herds were from farms designated as "traditional" dairy systems. These were small (average 18.6 ha of cultivated land) with a small number of cows (average 28) kept tied all year round in old facilities, and fed mainly meadow hay and small amount of compound feeds (about 18\% of DMI). Milking was mechanically carried out at individual stalls. The 56 farms designated as "modern" dairy systems were larger, with more cows (average 45) kept in free stalls and milked in milking parlors. The feeding regimen of 30 of these modern farms did not use TMR, and was often similar to traditional farms but with more compound feed per cow (about 30\% DMI). Of the 26 dairy farms using TMR (concentrates accounting for about $50 \%$ of DMI), 9 included corn silage in the diet and 17 added water to moisten the TMR. The farms were sampled once in a calendar year to ensure that the various dairy systems were evenly distributed throughout the year, except in August.

\section{Milk Sampling and Cows}

A total of 1,158 Brown Swiss cows (a maximum of 15 cows per herd) were sampled once during the evening milking. Two milk subsamples per cow were 
immediately refrigerated $\left(4^{\circ} \mathrm{C}\right)$ without preservative. One subsample $(50 \mathrm{~mL})$ was taken to the Milk Quality Laboratory of the Breeders' Federation of Trento Province (Trento, Italy) for milk fat and protein analysis with a Milkoscan FT6000 (Foss Electric A/S, Hillerød, Denmark), whereas the other $(2,000 \mathrm{~mL})$ was taken to the Cheese-Making Laboratory of the Department of Agronomy, Food, Natural Resources, Animals and Environment of the University of Padova (Legnaro, Padova, Italy) for FA analysis and model cheese-making.

To correct the milk yield for milk fat and protein contents, in accordance with van Lingen et al. (2014) and CVB (2008), a correcting factor (CF) was calculated as follows:

$$
\begin{aligned}
\mathrm{CF} & =0.337+0.116 \times \text { milk-fat }(\%) \\
& +0.06 \times \text { milk-protein }(\%) .
\end{aligned}
$$

The individual daily fat- and protein-corrected milk yield $(\mathbf{d C M Y})$ value $(\mathrm{kg} / \mathrm{d})$ of each cow was calculated on the basis of its milk yield (dMY) on the day of sampling as follows:

$$
\operatorname{dCMY}(\mathrm{kg} / \mathrm{d})=\operatorname{dMY}(\mathrm{kg} / \mathrm{d}) \times \mathrm{CF} .
$$

Details of the milk analysis are reported in CipolatGotet et al. (2013). Data on the cows and herds were provided by the Superbrown Consortium of Bolzano and Trento (Italy).

\section{Milk Fatty Acid Analysis}

Fatty acid methyl esters were prepared by the direct extraction and alkali-catalyzed trans-methylation procedure, described by Feng et al. (2004). A detailed description of the procedure is reported in Pegolo et al. (2016a). Briefly, the FA composition was determined using a ThermoQuest gas chromatograph (Thermo Electron Corp., Waltham, MA) fitted with a flameionization detector and a high polar fused-silica capillary column (Chrompack CP-Sil88 Varian, Middelburg, the Netherlands; $100 \mathrm{~m}, 0.25 \mathrm{~mm}$ i.d.; film thickness $0.20 \mu \mathrm{m})$. Individual FA methyl esters were identified by comparison with standard mixtures, pure standards, and published GC profiles. The GC column used yields a detailed composition, including more cis and trans isomers of 16:1, 16:2, 18:1, 18:2, and 18:3. Given the large number of samples in this study, we preferred to carry out a single-run analysis per sample by applying a temperature gradient capable of separating the main 16:1, 18:1, 18:2, and 18:3 isomers.

We used a reference standard butter (BCR 164; Commission of the European Communities, Community
Bureau of Reference, Brussels, Belgium) to estimate correction factors for the short-chain FA, as previously described by Mele et al. (2008). Inter- and intraassay coefficients of variation were also calculated using the same reference standard butter, with the analytical limit of detection set at $0.001 \%$ above that of the total amount of FA. Milk FA composition was expressed as grams per $100 \mathrm{~g}$ of total FA.

\section{Prediction of Methane Emission}

Methane yield [i.e., the emission (g) per $\mathrm{kg}$ of DMI $\left.\left(\mathrm{CH}_{4} / \mathrm{DMI}\right)\right]$ was estimated according to the van Lingen et al. (2014) equation:

$$
\begin{gathered}
\mathrm{CH}_{4} / \mathrm{DMI}(\mathrm{g} / \mathrm{kg})=23.39+9.74 \times \mathrm{C} 16: 0 \text { iso } \\
-1.06 \times \mathrm{C} 18: 1 \text { trans- } 10+\text { trans }-11-1.75 \\
\times \mathrm{C} 18: 2 \text { cis }-9, \text { cis }-12
\end{gathered}
$$

where $\mathrm{C} 16: 0$ iso is iso-palmitic acid, C18:1 trans$10+$ trans -11 is the sum of $i s o$-oleic and vaccenic acids, and C18:2 cis-9,cis-12 is the linoleic acid of milk, all expressed as a percentage of the sum of all milk FA.

Methane intensity per unit of milk [i.e., $\mathrm{CH}_{4}$ emission (g) per $\mathrm{kg}$ of $\left.\mathrm{CM}\left(\mathrm{CH}_{4} / \mathrm{CM}\right)\right]$ was estimated according to the van Lingen et al. (2014) equation:

$$
\begin{gathered}
\mathrm{CH}_{4} / \mathrm{CM}(\mathrm{g} / \mathrm{kg})=21.13-1.38 \times \mathrm{C} 4: 0+8.53 \\
\times \mathrm{C} 16: 0 \text { iso }-0.22 \times \mathrm{C} 18: 1 \text { cis- }-9-0.59 \\
\times \mathrm{C} 18: 1 \text { trans }-10+\text { trans }-11
\end{gathered}
$$

where C4:0 is butyric acid and C18:1 cis-9 is oleic acid, both expressed as a percentage of the sum of all milk FA.

In addition, the estimated daily methane production per cow $\left(\mathbf{d C H}_{\mathbf{4}}\right)$ was calculated as

$$
\mathrm{dCH}_{4}(\mathrm{~g} / \mathrm{d})=\mathrm{CH}_{4} / \mathrm{CM} \times \mathrm{dCMY} .
$$

The estimated methane intensity per kilogram of fresh cheese $\left(\mathbf{C H}_{4} / \mathbf{C Y}_{\text {CURD }}\right)$ and per kilogram of cheese solids $\left(\mathbf{C H}_{4} / \mathbf{C Y}_{\text {Solids }}\right)$ were calculated, respectively, as

$$
\begin{gathered}
\mathrm{CH}_{4} / \mathrm{CY}_{\mathrm{CURD}}(\mathrm{g} / \mathrm{kg})=\mathrm{dCH}_{4} / \mathrm{dCY}_{\mathrm{CURD}} \text { and } \\
\mathrm{CH}_{4} / \mathrm{CY}_{\text {SOLIDS }}(\mathrm{g} / \mathrm{kg})=\mathrm{dCH}_{4} / \mathrm{dCY}_{\text {SOLIDS}} \text {. }
\end{gathered}
$$

The daily production of fresh cheese $\left(\mathbf{d C Y}_{\mathbf{C U R D}}, \mathrm{kg} / \mathrm{d}\right)$ and of cheese solids $\left(\mathbf{d C} \mathbf{Y}_{\text {SoliDs }}, \mathrm{kg} / \mathrm{d}\right)$ are described in the next paragraph. 
Last, being aware of potential differences (e.g., breed, environment, and diets) between previous studies and this one, and to test the coherence of the van Lingen et al. (2014) equations when applied in a different situation, the daily DMI of each cow $\left(\mathbf{d D M I}_{\text {est }}\right)$ was indirectly estimated as

$$
\mathrm{dDMI}_{\text {est }}(\mathrm{kg} / \mathrm{d})=\mathrm{dCH}_{4} /\left(\mathrm{CH}_{4} / \mathrm{DMI}\right) \text {. }
$$

\section{Model Cheese Making}

Model cheeses were made from the larger milk sample from each cow under the conditions frequently used to produce short-ripened cheeses and according to the procedure previously described in detail by Cipolat-Gotet et al. (2013). Briefly, after heating $1,500 \mathrm{~mL}$ of milk to $35^{\circ} \mathrm{C}$ in small stainless-steel vats, the thermophilic starter culture was added, then rennet, and the mixture was then allowed to coagulate for a controlled length of time. The resulting curd was removed from the vat, drained, shaped into a wheel, pressed, salted, weighed, sampled, and analyzed. The whey was collected from each vat and weighed, sampled, and analyzed. All the processed milk samples coagulated within the standard testing time and yielded a model cheese. Individual cheese yield was expressed as the ratio between the weight of the fresh cheese wheel and the weight of milk processed $\left(\mathbf{\%} \mathbf{C Y} \mathbf{Y}_{\mathbf{C U R D}}\right)$, and as the ratio between the weight of the fresh wheel multiplied by its percentage DM and the weight of the milk processed (\% $\left.\mathbf{C Y}_{\text {SOLIDS }}\right)$. Individual daily productions $(\mathrm{kg} / \mathrm{d})$ of fresh cheese $\left(\mathrm{dCY}_{\mathrm{CURD}}\right)$ and of cheese solids $\left(\mathrm{dCY}_{\text {SOLIDS }}\right)$ were calculated by multiplying the traits concerned (\% $\mathrm{CY}_{\mathrm{CURD}}$ or $\left.\% \mathrm{CY}_{\text {SOLIDS }}\right)$ by dMY.

\section{Statistical Analysis}

All aforementioned traits, which were tested for their normal distributions, were analyzed with the following mixed linear model:

$y_{i j k l m}=\mu+$ dairy system $_{i}+$ herd $_{j}(\text { dairy system })_{i}+$ parity $_{k}$ $+D I M_{l}+e_{i j k l m}$,

where $y_{i j k l m}$ is the observed trait; $\mu$ is the overall mean; dairy system si $_{i}$ is the fixed effect of the $i$ th dairy system $(i=1$ to 4$) ;$ herd $_{j}$ (dairy system $)_{i}$ is the random effect of the $j$ th herd ( $j=1$ to 85$)$ within the $i$ th dairy system; parity $_{k}$ is the fixed effect of the $k$ th parity $(k=1$ to 4 or more lactations); $D I M_{l}$ is the $l$ th 30 -d class of DIM, 11 classes; and $e_{i j k l m}$ is the residual random error term. Herd and residuals were assumed to be normally distributed with a mean of zero and variance $\sigma_{h}^{2}$ and $\sigma_{e}^{2}$, respectively. The significance of dairy system was tested on the error line of herd within dairy system, that of parity and DIM class on the error line of the residual variance. Proportion of variance explained by herd was calculated by dividing the corresponding variance component by the total variance.

Orthogonal post hoc contrasts $(P<0.05)$ were built for dairy system and parity factors: $(1)$ the "traditional" dairy system was compared with the "modern" systems; (2) within the modern systems, the "no TMR" herds were compared with the TMR herds; (3) within the TMR herds, those using silage were compared with those using water. In addition, first, second, and third parities were each compared with greater parities.

For the effect of DIM, first-order comparison measured linear relationship, whereas second- and thirdorder comparison measured the quadratic and cubic relationship, respectively. According to the contrasts results, linear, quadratic, or cubic trend lines were then reported in the figures, together with equation and coefficient of determination $\left(\mathrm{R}^{2}\right)$ of the regression and $P$-value of the polynomial contrast.

\section{RESULTS}

\section{Descriptive Statistics}

Descriptive statistics of the traits used for EME prediction (milk production, cheese yield, and informative milk FA) and of the EME estimates are listed in Table 1.

The methane yield per kilogram of DMI and methane intensity per kilogram of CM estimated using the equations of van Lingen et al. (2014) were, respectively, $21.3 \pm 1.6$ and $14.2 \pm 1.8 \mathrm{~g} / \mathrm{kg}$. We used the output of the 2 equations to also estimate the total methane production per cow per day $(357 \pm 109 \mathrm{~g} / \mathrm{d})$, and the methane intensity per kilogram of fresh cheese $(99.8 \pm$ $16.4 \mathrm{~g})$ and per kilogram of cheese solids $(207.5 \pm 30.9$ g). All the investigated traits had normal distributions.

\section{Analysis of Variance}

Table 2 summarizes the results of the statistical analyses of predictors and predicted traits. The informative FA proposed by van Lingen et al. (2014) for estimating $\mathrm{CH}_{4} / \mathrm{DMI}$ and $\mathrm{CH}_{4} / \mathrm{CM}$ were differently affected by dairy system ( 3 of the $6 \mathrm{FA}$ ), parity ( 3 of the 6 ), and DIM (all but one). They were also characterized by very wide variability among herds within dairy system, which was greater than the variability in milk production and cheese yield traits (Figure 1), with the only exception of the major FA, oleic acid, which had 
Table 1. Descriptive statistics of the estimated enteric methane emissions traits and the traits used for estimations

\begin{tabular}{|c|c|c|c|c|}
\hline Trait & Mean & SD & $\mathrm{P} 1^{1}$ & $\mathrm{P} 99^{1}$ \\
\hline \multicolumn{5}{|l|}{ Milk production trait ${ }^{2}$} \\
\hline Milk yield (dMY), $\mathrm{kg} / \mathrm{d}$ & 24.5 & 7.9 & 8.9 & 45.9 \\
\hline Milk fat, $\%$ & 4.23 & 0.72 & 2.69 & 6.43 \\
\hline Milk protein, \% & 3.71 & 0.43 & 2.86 & 4.79 \\
\hline Correcting factor & 1.05 & 0.09 & 0.85 & 1.33 \\
\hline dCMY, kg/d & 25.6 & 8.1 & 9.9 & 49.3 \\
\hline \multicolumn{5}{|l|}{ Cheese yield trait ${ }^{3}$} \\
\hline$\% \mathrm{CY}_{\mathrm{CURD}}, \%$ & 15.06 & 1.89 & 11.01 & 19.67 \\
\hline$\% \mathrm{CY}_{\text {SOLIDS }}, \%$ & 7.23 & 0.94 & 5.36 & 9.92 \\
\hline $\mathrm{dCY} Y_{\mathrm{CURD}}, \mathrm{kg} / \mathrm{d}$ & 3.66 & 1.17 & 1.41 & 8.85 \\
\hline $\mathrm{dCY}_{\text {SOLIDS }}, \mathrm{k} / \mathrm{d}$ & 1.76 & 0.57 & 0.67 & 3.32 \\
\hline \multicolumn{5}{|l|}{ Informative milk FA, ${ }^{4} \% \mathrm{FA}$} \\
\hline 4:0 (butyric acid) & 3.45 & 0.90 & 1.46 & 5.84 \\
\hline 16:0 iso (iso-palmitic acid) & 0.32 & 0.09 & 0.11 & 0.56 \\
\hline $18: 1$ trans-10 (iso-oleic acid) & 0.29 & 0.09 & 0.13 & 0.61 \\
\hline 18:1 trans -11 (vaccenic acid) & 1.20 & 0.37 & 0.42 & 2.22 \\
\hline 18:1 cis-9 (oleic acid) & 18.33 & 3.19 & 12.66 & 29.27 \\
\hline \multirow{2}{*}{\multicolumn{5}{|c|}{ Estimated methane emissions ${ }^{5}$}} \\
\hline & & & & \\
\hline $\mathrm{CH}_{4} / \mathrm{DMI}, \mathrm{g} / \mathrm{kg}$ & 21.34 & 1.60 & 17.48 & 24.68 \\
\hline $\mathrm{CH}_{4} / \mathrm{CM}, \mathrm{g} / \mathrm{kg}$ & 14.17 & 1.78 & 8.71 & 17.55 \\
\hline $\mathrm{dCH}_{4}, \mathrm{~g} / \mathrm{d}$ & 357 & 109 & 140 & 676 \\
\hline $\mathrm{CH}_{4} / \mathrm{CY}_{\mathrm{CURD}}, \mathrm{g} / \mathrm{kg}$ & 99.8 & 16.4 & 61.9 & 140.3 \\
\hline $\mathrm{CH}_{4} / \mathrm{CY}_{\text {SOLIDS }}, \mathrm{g} / \mathrm{kg}$ & 207.5 & 30.9 & 125.0 & 279.7 \\
\hline $\mathrm{dDMI}_{\text {est }},{ }^{6} \mathrm{~kg} / \mathrm{d}$ & 16.9 & 5.5 & 6.0 & 32.4 \\
\hline \multicolumn{5}{|c|}{${ }^{1} \mathrm{P} 1=1$ st percentile; $\mathrm{P} 99=99 \mathrm{th}$ percentile. } \\
\hline \multicolumn{5}{|c|}{${ }^{2} \mathrm{dCMY}=$ daily fat- and protein-corrected milk yield. } \\
\hline \multicolumn{5}{|c|}{$\begin{array}{l}{ }^{3} \% \mathrm{CY}_{\mathrm{CURD}}=\text { weight of fresh cheese as a percentage of processed milk; } \% \mathrm{CY} \mathrm{Y}_{\text {SOLIDS }}=\text { weight of cheese solids } \\
\text { as a percentage of processed milk; } \mathrm{dCY} \mathrm{Y}_{\mathrm{CURD}}=\text { daily production of fresh cheese per cow; } \mathrm{dCY} \mathrm{Y}_{\text {SOLIDS }}=\text { daily } \\
\text { production of cheese solids. }\end{array}$} \\
\hline \multicolumn{5}{|c|}{$\begin{array}{l}{ }^{4} \text { Informative milk FA are the fatty acids included as independent variables in the equations used to estimate } \\
\text { the enteric methane emissions (van Lingen et al., 2014). }\end{array}$} \\
\hline \multicolumn{5}{|c|}{$\begin{array}{l}{ }^{5} \mathrm{CH}_{4} / \mathrm{DMI}=\text { methane yield, emitted per kilogram of } \mathrm{DMI} ; \mathrm{CH}_{4} / \mathrm{CM}=\text { methane intensity, emitted per kilo- } \\
\text { gram of fat- and protein-corrected milk produced; } \mathrm{dCH}_{4}=\text { daily methane production per cow; } \mathrm{CH}_{4} / \mathrm{CY}_{\mathrm{CURD}} \\
=\text { methane intensity per kilogram of fresh cheese produced; } \mathrm{CH}_{4} / \mathrm{CY}_{\text {SOLIDS }}=\text { methane intensity per kilogram } \\
\text { of cheese solids produced. }\end{array}$} \\
\hline${ }^{6} \mathrm{dDMI}_{\text {est }}=$ estimated daily DMI & & & & \\
\hline
\end{tabular}

a much lower herd variability, similar to the variability in milk fat content.

It can also be seen from Table 2 that all the EME traits were affected by dairy system, but as Figure 1 shows, they all also displayed wide variability among individual farms within dairy system, as evidenced by the corresponding variance, which ranged from 0.333 for $\mathrm{dCH}_{4}$ to 0.609 for $\mathrm{CH}_{4} / \mathrm{DMI}$ of the total variance of the traits. Moreover, all EME traits were affected by parity (with the only exception of $\mathrm{CH}_{4} / \mathrm{DMI}$ ) and DIM of individual cows (Table 2).

\section{Sources of Variation}

Table 3 summarizes the results from the statistical analysis of the effects of dairy system on all the traits used and obtained. As can be seen, mean estimated methane yield $\left(\mathrm{CH}_{4} / \mathrm{DMI}\right)$ was slightly greater in traditional than in modern dairy systems, but not methane intensity per unit of milk $\left(\mathrm{CH}_{4} / \mathrm{CM}\right)$ and fresh cheese $\left(\mathrm{CH}_{4} / \mathrm{CY}_{\mathrm{CURD}}\right)$ per cow. Farms operating the traditional dairy system had slightly greater methane intensity per unit of cheese solids $\left(\mathrm{CH}_{4} / \mathrm{CY}_{\text {SOLIDS }}\right)$ than modern farms, whereas they were much lower in terms of methane production per cow per day, reflecting their lower milk yield. Again, the lower dMY (and daily intake of DM, $\mathbf{d D M I}$ ) is the main reason why methane production $\left(\mathrm{dCH}_{4}\right)$ was lower in modern farms not using TMR in the feed than those using mixer wagons. The other estimated EME traits were not affected by whether or not TMR was used. Instead, we point out that, within the dairy systems using TMR, farms that included silage in the diet as a moist feedstuff (corn silage, and sometimes also grass silage), rather than moistening dry feeds with water, had greater estimated EME, regardless of how these are expressed (Table 3).

Table 4 summarizes the effects of parity on estimated EME traits and on the traits used for estimating them. 
Table 4 shows that the 3 MUFA with 18 carbon chains decreased from primiparous to multiparous cow milk, whereas the 2 SFA and the PUFA were unaffected by parity.

As expected, given the increase in dMY (and also $\mathrm{dDMI}), \mathrm{dCH}_{4}$ increases with increasing parity, especially from the first to those subsequent. Estimated methane yield $\left(\mathrm{CH}_{4} / \mathrm{DMI}\right)$ were not affected by parity, whereas methane intensity per unit of milk, fresh cheese, or cheese solids increased from first to second and subsequent parities.

As already seen (Table 2), we found lactation stage to be a very important source of variability for almost all the predictors and all of the predicted traits. Although milk production and cheese yield traits followed the expected patterns, except for the $2 \mathrm{FA}$ with the low- est proportions in the milk (iso-palmitic and iso-oleic acids), the patterns displayed by the most abundant FA, all of which had negative relationships with EME traits (van Lingen et al., 2014), were curvilinear during lactation, their proportions decreasing during early lactation, then becoming more stable in mid and late lactation (Figure 2). Of the 2 minor FA, iso-palmitic acid, characterized by a strong positive relationship with EME (van Lingen et al., 2014), increased linearly during lactation, whereas 18:1 trans-10 (iso-oleic acid) was unaffected by DIM classes.

As a consequence of variations in the FA, estimated $\mathrm{CH}_{4} / \mathrm{DMI}$ increased across all lactation stages, whereas estimated $\mathrm{CH}_{4} / \mathrm{CM}$ mainly increased during early lactation and tended to stabilize thereafter (Figure 3). We also observed that the estimated methane intensity per

Table 2. ANOVA ( $F$ - and $P$-values) of the estimated enteric methane emissions traits and related phenotypes

\begin{tabular}{|c|c|c|c|c|}
\hline Item & $\begin{array}{c}\text { Dairy system } \\
F \text {-value }\end{array}$ & $\begin{array}{l}\text { Parity } \\
F \text {-value }\end{array}$ & $\begin{array}{c}\text { DIM } \\
F \text {-value }\end{array}$ & $\begin{array}{l}\text { Residual } \\
\text { RMSE }^{2}\end{array}$ \\
\hline df & 3 & 3 & 10 & - \\
\hline \multicolumn{5}{|l|}{ Milk production trait ${ }^{3}$} \\
\hline $\mathrm{dMY}, \mathrm{kg} / \mathrm{d}$ & $16.8^{* * *}$ & $41.8^{* * *}$ & $69.7^{* * *}$ & 4.71 \\
\hline Milk fat, $\%$ & $4.2^{* *}$ & 0.2 & $6.5^{* * *}$ & 0.64 \\
\hline Milk protein, \% & $4.7^{* *}$ & $11.8^{* * *}$ & $101.7^{* * *}$ & 0.28 \\
\hline Correcting factor & $4.5^{* *}$ & 1.3 & $18.9^{* * *}$ & 0.08 \\
\hline dCMY, kg/d & $19.6^{* * *}$ & $34.7^{* * *}$ & $45.9^{* * *}$ & 5.20 \\
\hline \multicolumn{5}{|l|}{ Cheese yield trait ${ }^{4}$} \\
\hline$\% \mathrm{CY}_{\mathrm{CURD}}, \%$ & $3.3^{*}$ & $9.2^{* * *}$ & $26.8^{* * *}$ & 1.43 \\
\hline$\% \mathrm{CY}_{\text {SOLIDS }}, \%$ & $8.6^{* * *}$ & 1.5 & $22.3^{* * *}$ & 0.77 \\
\hline $\mathrm{dCY}_{\mathrm{CURD}}, \mathrm{kg} / \mathrm{d}$ & $18.6^{* * *}$ & $24.5^{* * *}$ & $34.9^{* * *}$ & 0.75 \\
\hline $\mathrm{dCY}_{\text {SOLIDS }}, \mathrm{k} / \mathrm{d}$ & $23.0^{* * *}$ & $31.8^{* * *}$ & $33.0^{* * *}$ & 0.37 \\
\hline \multicolumn{5}{|l|}{ Informative milk FA ${ }^{5} \% \mathrm{FA}$} \\
\hline 4:0 (butyric acid) & 2.5 & 0.7 & $25.2^{* * *}$ & 0.56 \\
\hline 16:0 iso (iso-palmitic acid) & $13.9^{* * *}$ & 2.3 & $16.3^{* * *}$ & 0.06 \\
\hline 18:1 trans-10 (iso-oleic acid) & 1.5 & $7.6^{* * *}$ & 1.6 & 0.07 \\
\hline 18:1 trans-11 (vaccenic acid) & $23.4^{* * *}$ & $24.6^{* * *}$ & $7.3^{* * *}$ & 0.22 \\
\hline $18: 1$ cis-9 (oleic acid) & 2.5 & $9.9 * * *$ & $25.3^{* * *}$ & 2.61 \\
\hline 18:2 cis-9,cis-12 (linoleic acid) & $15.0^{* * *}$ & 0.8 & $5.2^{* * *}$ & 0.34 \\
\hline \multicolumn{5}{|l|}{ Estimated methane emissions ${ }^{6}$} \\
\hline $\mathrm{CH}_{4} / \mathrm{DMI}, \mathrm{g} / \mathrm{kg}$ & $15.9^{* * *}$ & 0.2 & $22.8^{* * *}$ & 0.84 \\
\hline $\mathrm{CH}_{4} / \mathrm{CM}, \mathrm{g} / \mathrm{kg}$ & $6.0^{* * *}$ & $5.5^{* * *}$ & $54.9 * * *$ & 1.06 \\
\hline $\mathrm{dCH}_{4}, \mathrm{~g} / \mathrm{d}$ & $16.4^{* * *}$ & $43.3^{* * *}$ & $25.3^{* * *}$ & 73.7 \\
\hline $\mathrm{CH}_{4} / \mathrm{CY}_{\text {CURD }}, \mathrm{g} / \mathrm{kg}$ & $5.1^{* *}$ & $14.1^{* * *}$ & $25.6^{* * *}$ & 10.1 \\
\hline $\mathrm{CH}_{4} / \mathrm{CY}_{\text {SOLIDS }}, \mathrm{g} / \mathrm{kg}$ & $7.6^{* * *}$ & $4.8^{* *}$ & $28.3^{* * *}$ & 19.7 \\
\hline $\mathrm{dDMI}_{\text {est }},{ }^{7} \mathrm{~kg} / \mathrm{d}$ & $18.4^{* * *}$ & $39.2^{* * *}$ & $28.1^{* * *}$ & 3.61 \\
\hline
\end{tabular}

${ }^{1}$ The variance of herd/date within dairy system, expressed as a ratio with total variance (herd plus residual), is given in Figure 1.

${ }^{2} \mathrm{RMSE}=$ root mean squared error.

${ }^{3} \mathrm{dCMY}=$ daily fat- and protein-corrected milk yield.

${ }^{4} \% \mathrm{CY}_{\mathrm{CURD}}=$ weight of fresh cheese as a percentage of processed milk; $\% \mathrm{CY}_{\text {SOLIDS }}=$ weight of cheese solids as a percentage of processed milk; $\mathrm{dCY}_{\mathrm{CURD}}=$ daily production of fresh cheese per cow; $\mathrm{dCY}$ SOLIDS $=$ daily production of cheese solids.

${ }^{5}$ Informative milk FA are the fatty acids included as independent variables in the equations used to estimate the enteric methane emissions (van Lingen et al., 2014).

${ }^{6} \mathrm{CH}_{4} / \mathrm{DMI}=$ methane yield, emitted per kilogram of DMI; $\mathrm{CH}_{4} / \mathrm{CM}=$ methane intensity, emitted per kilogram of fat- and protein-corrected milk produced; $\mathrm{dCH}_{4}=$ daily methane production per cow; $\mathrm{CH}_{4} / \mathrm{CY}_{\mathrm{CURD}}$ $=$ methane intensity per kilogram of fresh cheese produced; $\mathrm{CH}_{4} / \mathrm{CY}_{\text {SOLIDS }}=$ methane intensity per kilogram of cheese solids produced.

${ }^{7} \mathrm{dDMI}_{\text {est }}=$ estimated daily DMI of cows.

${ }^{*} P<0.05$; ** $P<0.01$; ${ }^{* * *} P<0.001$. 


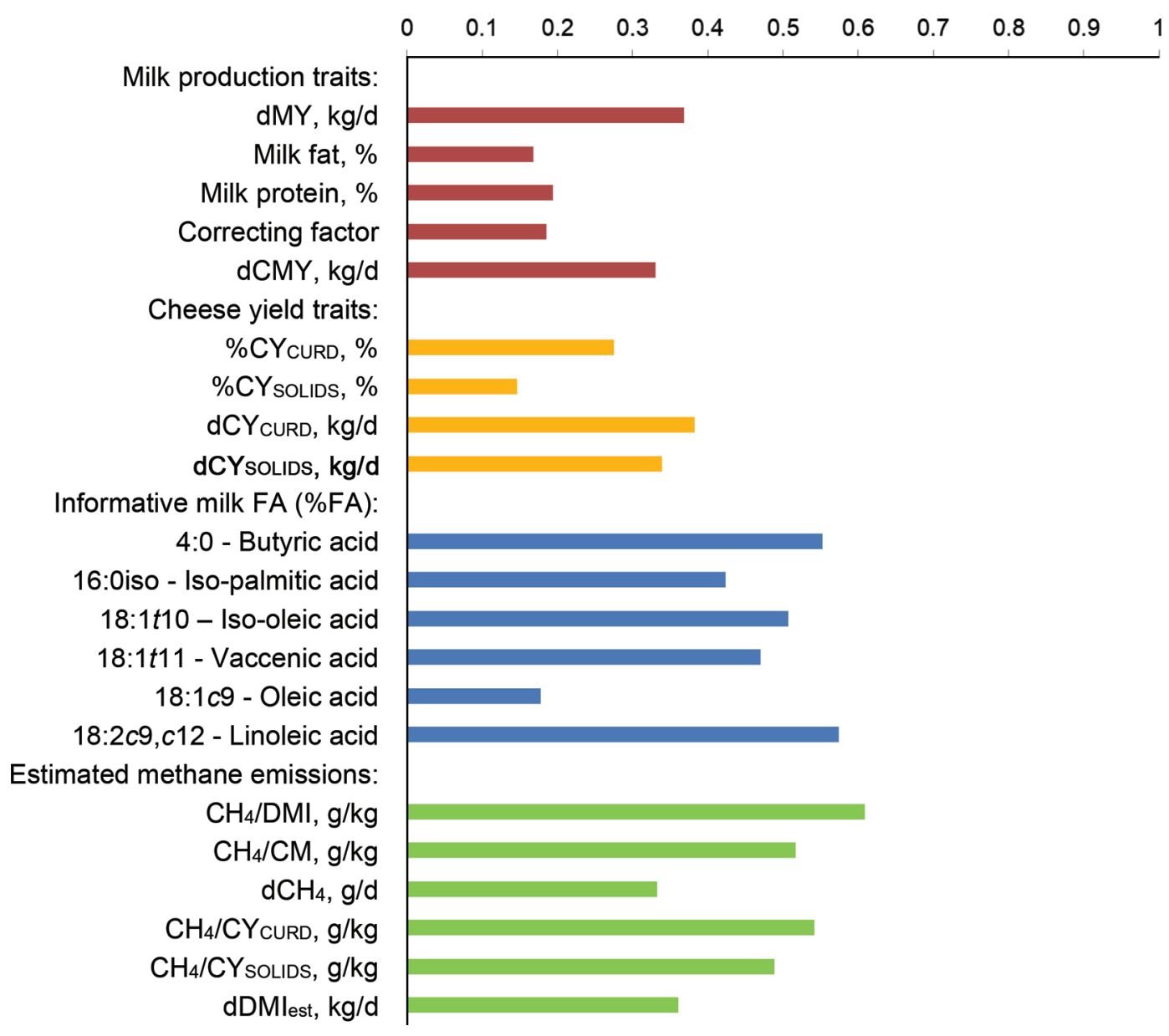

Figure 1. Incidence of variance of herd within dairy system on total variance. $\mathrm{dCMY}=$ daily fat- and protein-corrected milk. $\% \mathrm{CY}$ CURD $=$ weight of fresh cheese as a percentage of processed milk; $\% \mathrm{CY}_{\text {SOLIDS }}=$ weight of cheese solids as a percentage of processed milk; $\mathrm{dCY}$ CURD $=$ daily production of fresh cheese per cow; $\mathrm{dCY}_{\text {Solids }}=$ daily production of cheese solids. Informative milk FA are the fatty acids included as

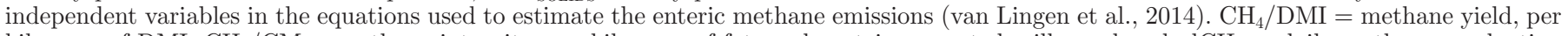
kilogram of DMI; $\mathrm{CH}_{4} / \mathrm{CM}=$ methane intensity, per kilogram of fat- and protein-corrected milk produced; dCH $\mathrm{CH}_{4}=$ daily methane production per cow; $\mathrm{CH}_{4} / \mathrm{CY}_{\mathrm{CURD}}=$ methane intensity per kilogram of fresh cheese produced; $\mathrm{CH}_{4} / \mathrm{CY}_{\text {SOLIDS }}=$ enteric methane emitted per kilogram of cheese solids produced. $\mathrm{dDMI}_{\mathrm{est}}=$ estimated daily DMI of cows. Color version available online.

kilogram of fresh cheese and cheese solids and those per kilogram of milk had similar patterns (Figure 4). Given that milk yield decreased across all lactation stages (Figure 3), and that the estimated EME expressed as both per unit of milk and DMI increased during early lactation and stabilized thereafter, it is not unexpected that total estimated $\mathrm{dCH}_{4}$ increased during early lactation and then decreased during mid and late lactation (Figure 4). This pattern is consistent with the indirect prediction of DMI to slightly increase till mid lactation and decrease thereafter.

\section{DISCUSSION}

Most traits relative to milk production and quality, cheese yield, and milk nutrient recovery in the curd have been reported and discussed in a previous study within the same project (Cipolat-Gotet et al., 2013), and they are included here only to provide a better understanding of the methane intensities per unit of cheese estimated from them. Also, the detailed FA profiles of all cows in the current survey have been previously analyzed and discussed for genetic parameters (Pegolo et al., 2016a). Besides this, some polymorphisms were tested using a candidate gene approach (Pegolo et al., 2016b) and recently a genomewide association and network analysis have also been explored (Pegolo et al., 2017). A multivariate analysis of the FA profiles has also been carried out (Mele et al., 2016) to identify their latent explanatory factors and the effects of dairy system, feeding, herd, parity, and stage of lactation. 


\section{EME Traits Estimated from Milk Fatty Acids}

It is well known that the milk FA originating from de novo synthesis by the mammary gland (including shortand mid-chain SFA) mainly reflect the availability of acetyl-CoA molecules, obtained from acetate produced in the rumen (Barber et al., 1997; Bernard et al., 2008), and that the production of acetate by rumen microbes causes an excess of hydrogen, which is used by methanogenic Archaea to produce methane (Bauman et al., 2006). Positive correlations between de novo FA and EME have often been reported (Chilliard et al., 2009;
Dijkstra et al., 2011; Rico et al., 2016). Furthermore, van Lingen et al. (2014) also reported positive correlations between EME and relative proportions of FA 10:0, 12:0, 14:0, and 16:0 in the milk fat of dairy cows.

Negative correlations have been frequently found between EME and long-chain UFA (Chilliard et al., 2009; Dijkstra et al., 2011; Mohammed et al., 2011), due to oil-rich feeds inhibiting fiber fermentation in the rumen, responsible for most of the rumen acetate production, and corresponding inhibition of de novo synthesis of FA in the mammary gland of lactating female ruminants (Chilliard et al., 2000).

Table 3. Effects of the dairy system, the feed distribution techniques within modern farms, and the moisture source of TMR on the estimated enteric methane emissions traits and related phenotypes

\begin{tabular}{|c|c|c|c|c|c|c|c|}
\hline \multirow[b]{3}{*}{ Item } & \multicolumn{4}{|c|}{ Dairy system LSM } & \multirow{2}{*}{\multicolumn{3}{|c|}{$\begin{array}{c}\text { Orthogonal contrast } \\
F \text {-value }\end{array}$}} \\
\hline & \multirow[b]{2}{*}{ Traditional } & \multicolumn{3}{|c|}{ Modern } & & & \\
\hline & & $\begin{array}{l}\text { No } \\
\text { TMR }\end{array}$ & Silage & Water & $\begin{array}{l}\text { Modern vs. } \\
\text { traditional }^{1}\end{array}$ & $\begin{array}{l}\text { TMR vs. } \\
\text { no } \mathrm{TMR}^{2}\end{array}$ & $\begin{array}{l}\text { Silage vs } \\
\text { water }^{3}\end{array}$ \\
\hline Herds/cows (df) & $29 / 377$ & $30 / 407$ & 9/119 & $17 / 228$ & (1) & (1) & (1) \\
\hline Milk fat, $\%$ & 4.20 & 4.14 & 4.59 & 4.21 & 1.9 & $7.6^{* *}$ & $7.5^{* *}$ \\
\hline Milk protein, \% & 3.59 & 3.67 & 3.78 & 3.73 & $12.6^{* * *}$ & $4.3^{*}$ & 0.7 \\
\hline Correcting factor & 1.04 & 1.04 & 1.10 & 1.05 & $4.0^{*}$ & $8.4^{* *}$ & $6.8^{*}$ \\
\hline \multirow{2}{*}{\multicolumn{8}{|c|}{$\begin{array}{l}\mathrm{dCMY}, \mathrm{kg} / \mathrm{d} \\
\text { Cheese vield trait }^{5}\end{array}$}} \\
\hline & & & & & & & \\
\hline$\% \mathrm{CY}_{\mathrm{CURD}}, \%$ & 14.6 & 14.7 & 15.6 & 15.3 & $5.6^{*}$ & $6.9^{* *}$ & 0.8 \\
\hline$\% \mathrm{CY}_{\text {SOLIDS }}, \%$ & 6.9 & 7.1 & 7.6 & 7.4 & $20.6^{* * *}$ & $10.7^{* *}$ & 3.3 \\
\hline $18: 1$ trans-10 (iso-oleic acid) & 0.28 & 0.29 & 0.27 & 0.32 & 0.7 & 0.0 & 3.1 \\
\hline 18:1 trans-11 (vaccenic acid) & 1.32 & 1.33 & 0.73 & 1.02 & $28.7^{* * *}$ & $56.5^{* * *}$ & $10.6^{* *}$ \\
\hline $18: 1$ cis-9 (oleic acid) & 18.0 & 18.3 & 17.6 & 19.0 & 0.9 & 0.0 & $5.5^{*}$ \\
\hline 18:2 cis-9, cis-12 (linoleic acid) & 1.77 & 2.04 & 1.93 & 2.60 & $17.9^{* * *}$ & $4.1^{*}$ & $16.4^{* * *}$ \\
\hline \multicolumn{8}{|l|}{ Estimated methane emissions ${ }^{7}$} \\
\hline $\mathrm{CH}_{4} / \mathrm{DMI}, \mathrm{g} / \mathrm{kg}$ & 22.1 & 21.2 & 21.8 & 19.9 & $19.7^{* * *}$ & 1.1 & $19.2^{* * *}$ \\
\hline $\mathrm{CH}_{4} / \mathrm{CM}, \mathrm{g} / \mathrm{kg}$ & 14.4 & 14.1 & 14.9 & 13.1 & 1.2 & 0.1 & $14.1^{* * *}$ \\
\hline $\mathrm{dCH}_{4}, \mathrm{~g} / \mathrm{d}$ & 309 & 368 & 449 & 389 & $45.2^{* * *}$ & $11.1^{* * *}$ & $6.7^{*}$ \\
\hline $\mathrm{CH}_{4} / \mathrm{CY}_{\mathrm{CURD}}, \mathrm{g} / \mathrm{kg}$ & 103 & 100 & 105 & 91 & 2.5 & 0.5 & $9.7^{* *}$ \\
\hline $\mathrm{CH}_{4} / \mathrm{CY}_{\text {SOLIDS }}, \mathrm{g} / \mathrm{kg}$ & 217 & 206 & 214 & 188 & $8.5^{* *}$ & 0.9 & $9.6^{* *}$ \\
\hline $\mathrm{dDMI}_{\text {est }},{ }^{8} \mathrm{~kg} / \mathrm{d}$ & 14.0 & 17.5 & 20.6 & 19.6 & $52.7 * * *$ & $10.8^{* *}$ & 0.7 \\
\hline
\end{tabular}

${ }^{1}$ Contrast between the "traditional" dairy system versus the 3 "modern" ones.

${ }^{2}$ Contrast between the "modern no TMR" dairy system versus the 2 "modern TMR" ones.

${ }^{3}$ Contrast between the "modern TMR silage" dairy system versus the "modern TMR water" one.

${ }^{4} \mathrm{dCMY}=$ daily fat- and protein-corrected milk yield.

${ }^{5} \% \mathrm{CY}_{\text {CURD }}=$ weight of fresh cheese as a percentage of processed milk; $\% \mathrm{CY}_{\text {SOLIDS }}=$ weight of cheese solids as a percentage of processed milk; $\mathrm{dCY}_{\mathrm{CURD}}=$ daily production of fresh cheese per cow; $\mathrm{dCY}$ SOLIDS $=$ daily production of cheese solids .

${ }^{6}$ Informative milk FA are the fatty acids included as independent variables in the equations used to estimate the enteric methane emissions (van Lingen et al., 2014).

${ }^{7} \mathrm{CH}_{4} / \mathrm{DMI}=$ methane yield, emitted per kilogram of DMI; $\mathrm{CH}_{4} / \mathrm{CM}=$ methane intensity, emitted per kilogram of fat- and protein-corrected milk produced; $\mathrm{dCH}_{4}=$ daily methane production per cow; $\mathrm{CH}_{4} / \mathrm{CY}_{\mathrm{CURD}}=$ methane intensity per kilogram of fresh cheese produced; $\mathrm{CH} /$ $\mathrm{CY}_{\mathrm{SOLIDS}}=$ methane intensity per kilogram of cheese solids produced.

${ }^{8} \mathrm{dDMI}_{\text {est }}=$ estimated daily DMI of cows.

${ }^{*} P<0.05 ;{ }^{* *} P<0.01 ;{ }^{* * *} P<0.001$. 
Table 4. Effects of parity order on the estimated enteric methane emissions traits and related phenotypes

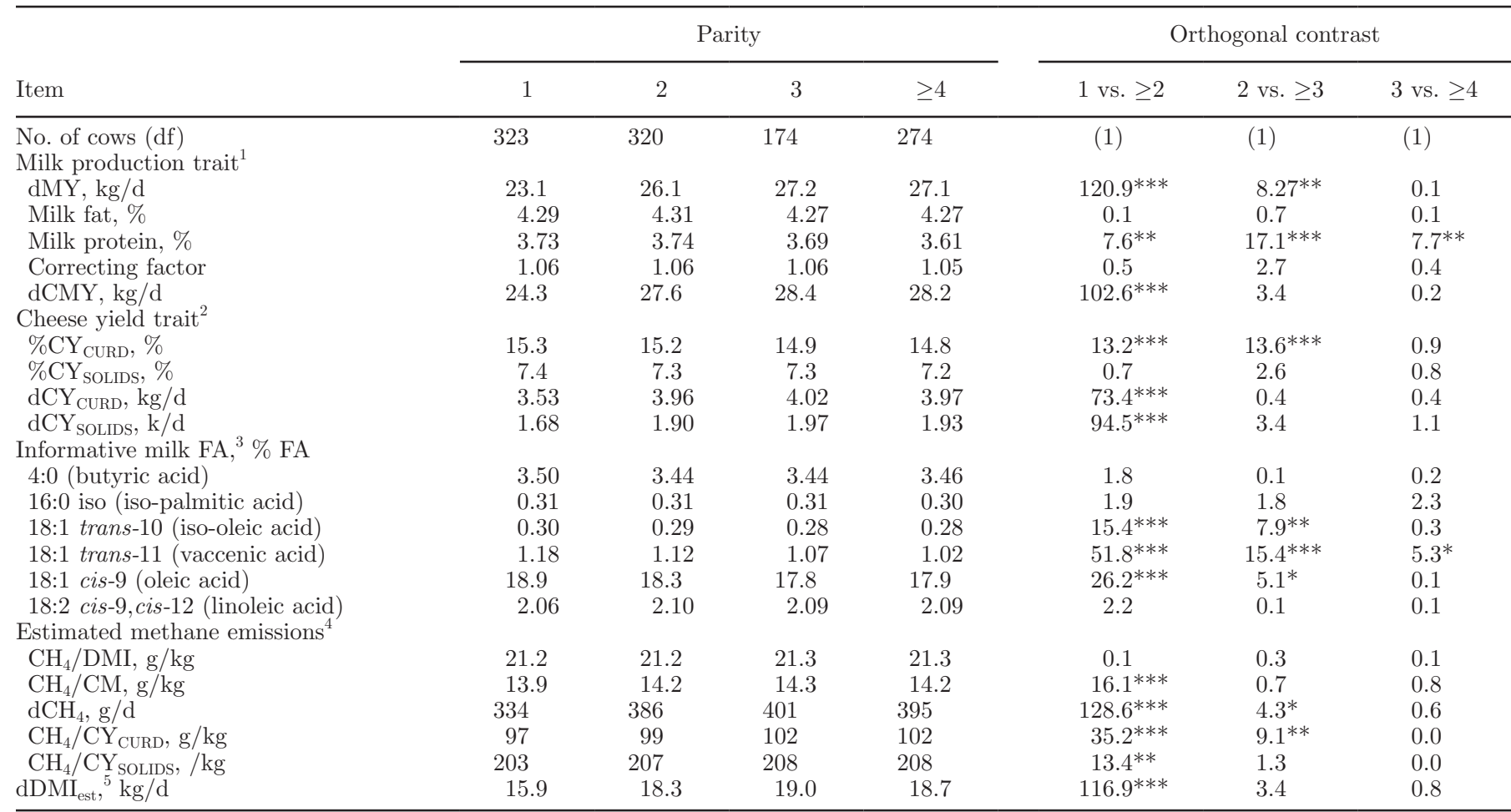

${ }^{1} \mathrm{dCMY}=$ daily fat- and protein-corrected milk yield.

${ }^{2} \% \mathrm{CY}_{\mathrm{CURD}}=$ weight of fresh cheese as a percentage of processed milk; $\% \mathrm{CY}_{\text {SOLIDS }}=$ weight of cheese solids as a percentage of processed milk; $\mathrm{dCY}_{\mathrm{CURD}}=$ daily production of fresh cheese per cow; $\mathrm{dCY}_{\text {SOLIDS }}=$ daily production of cheese solids.

${ }^{3}$ Informative milk FA are the fatty acids included as independent variables in the equations used to estimate the enteric methane emissions (van Lingen et al., 2014).

${ }^{4} \mathrm{CH}_{4} / \mathrm{DMI}=$ methane yield, emitted per kilogram of DMI; $\mathrm{CH}_{4} / \mathrm{CM}=$ methane intensity, emitted per kilogram of fat- and protein-corrected milk produced; $\mathrm{dCH}_{4}=$ daily methane production per cow; $\mathrm{CH}_{4} / \mathrm{CY}_{\mathrm{CURD}}=$ methane intensity per kilogram of fresh cheese produced; $\mathrm{CH}_{4} /$ $\mathrm{CY}_{\text {SOLIDS }}=$ methane intensity per kilogram of cheese solids produced.

${ }^{5} \mathrm{dDMI}_{\text {est }}=$ estimated daily DMI of cows.

${ }^{*} P<0.05 ;{ }^{* *} P<0.01 ;{ }^{* * *} P<0.001$.

The selection of FA to be included in multiple regressions for estimating EME traits is not based on simple correlations, but is instead aimed at optimizing the complex information emerging from the correlations between all the FA analyzed. An example of use of equations for predicting EME traits from milk FA profile developed in respiration chambers in a large-scale survey was carried out in the Netherlands. Three equations were obtained by Dijkstra et al. (2011) measuring methane yield with 10 dietary treatments from diets based on corn silage, grass silage, and concentrates, and different rumen active supplements. These equations were applied to the FA data of 1,905 first lactation Dutch Holstein-Friesian (van Engelen et al., 2015). The survey was finalized to the estimation of genetic parameters on methane yield, that had a very different result $\left(\mathrm{h}^{2}: 0.12\right.$ to 0.44$)$ according to the equation used even though the $\mathrm{R}^{2}$ of the equations were not much different (0.63 to 0.73$)$.
In the case of multiple regressions obtained from different trials, as in the case of meta-analyses, the procedure should also take into account the heterogeneity of the variances. The 2 equations for estimating $\mathrm{CH}_{4} / \mathrm{DMI}$ and $\mathrm{CH}_{4} / \mathrm{CM}$ put forward by van Lingen et al. (2014) were not those with the greatest $\mathrm{R}^{2}$ of the published equations (van Gastelen and Dijkstra, 2016), but they were used in this survey because they were obtained from a meta-analysis of 8 studies (treated as random effects in the model), which looked at 30 diets with different types of forage, forage:concentrate ratios, protein, fat, and sources of concentrates and supplements affecting rumen metabolism, so they were more representative of a variety of real situations than equations obtained from single experiments. Anyway, we note that the characteristics of the farms and cows sampled in this survey had some differences (breed, milk yield, forages, and so on) with those of the experiments summarized by van Lingen et al. (2014). Regarding the 
breed, Brown Swiss versus Holstein, a direct comparison between them is not available. In 911 Brown Swiss cows, Yin et al. (2015) found a daily methane production with a lower average and much lower standard

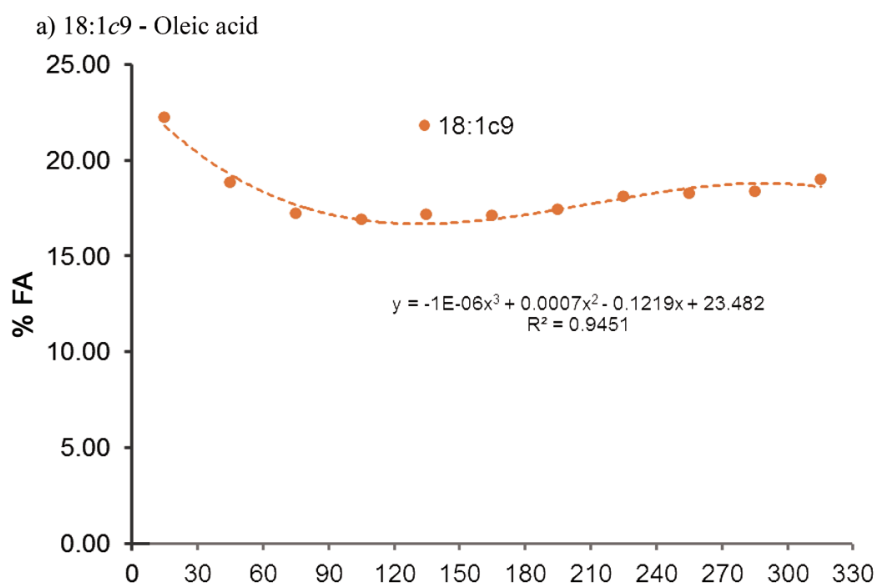

b) 4:0 - Butyric acid, 18:2c9,c12 - Linoleic acid and 18:1t11 - Vaccenic acid

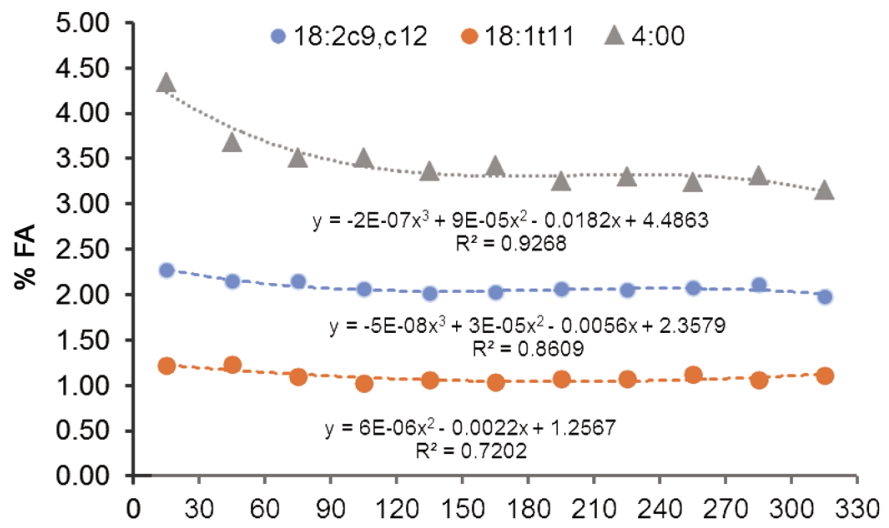

c) 16:0iso - Iso-Palmitic acid and 18:1t10 - Iso-Oleic acid

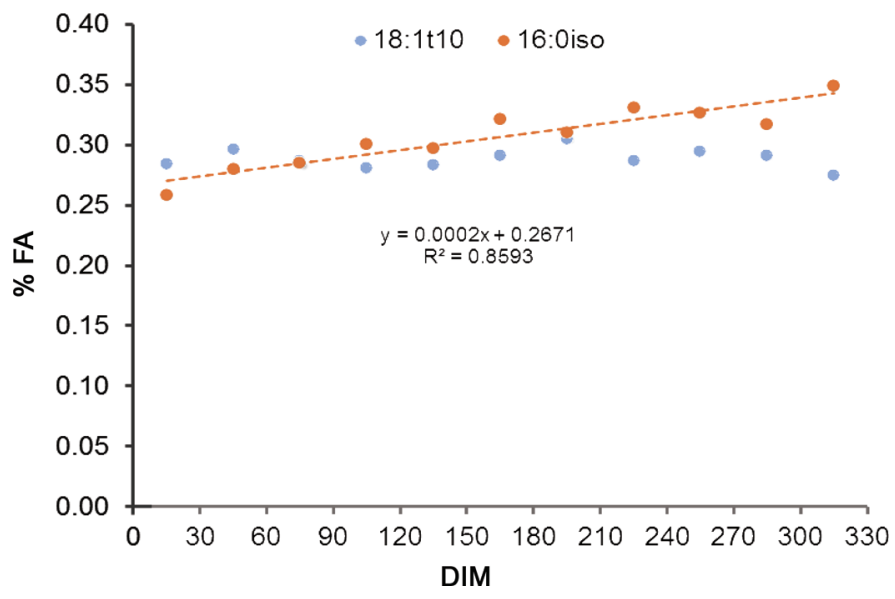

Figure 2. Effect of DIM on the informative milk fatty acids (\%/ $\Sigma F A$ ) used for predicting enteric methane emissions (EME) traits. $\mathrm{c}=$ cis, $\mathrm{t}=$ trans. Color version available online. deviation with respect to our results (281 \pm 20 vs. $357 \pm 109 \mathrm{~g} / \mathrm{d}$ ), but it should be considered that they simulated EME traits using only dMY and estimated BW as predictors and that the cows were reared in low input farms with much lower dMY $(19.3 \pm 4.4 \mathrm{~kg} / \mathrm{d})$ compared with our results $(24.5 \pm 7.9 \mathrm{~kg} / \mathrm{d})$ and those of van Lingen et al. $(28.9 \pm 6.4 \mathrm{~kg} / \mathrm{d})$.

Regarding the FA profile of milk, the differences among different breeds were generally related to milk yield and quality and to diet composition (Poulsen et al., 2012), especially when Jersey cows are compared with cows of other breeds, but the differences tended to disappear when fat content of milk was taken into account (Maurice-Van Eijndhoven et al., 2013). The average fat percentage of the milk samples of this survey was almost identical to that of the van Lingen et al. (2014) samples. The major effect of animal feeding on milk FA profile was found comparing indoor feeding with pasture, which was not sampled in both this survey and in the van Lingen et al. (2014) experiments, whereas minor effects were found comparing dried and ensiled forages, as reviewed by Shingfield et al. (2013).

Both equations were based on iso-palmitic acid (16:0iso), a FA whose proportion in milk fat is positively associated with $\mathrm{CH}_{4}$ production in the rumen. Rico et al. (2016) also found this FA to be positively correlated with EME. Although not highly correlated with de novo FA, it is positively correlated with other branched-chain FA, and negatively correlated with linoleic acid (Pegolo et al., 2016a). The de novo FA were not directly included in the equations. However, it should be noted that Mele et al. (2016) included oleic acid (18:1 cis-9), present in the equation for estimating methane intensity, in a multivariate latent explanatory factor of detailed milk FA profiles, called "de novo FA," factor together with the even mid-chain SFA, but with an opposite sign. This FA could, therefore, offer an indirect way to represent the relationships between mammary fat synthesis and EME.

The other FA included in the van Lingen et al. (2014) equations with negative signs are butyric acid (4:0), iso-oleic acid (18:1 trans-10) together with vaccenic acid (18:1 trans-11) and linoleic acid (18:2 cis-9,cis-12). Butyric acid of milk can be directly derived from blood $\mathrm{BHB}$, mainly derived from butyric acid produced in the rumen, which explains why it is not negatively affected by dietary UFA (Bernard et al., 2008; Shingfield et al., 2010). It should also be borne in mind that butyric acid is negatively correlated with myristic, myristoleic, palmitic, and palmitoleic acids (Pegolo et al., 2016a). Iso-oleic and vaccenic acids are included together in both of the equations of van Lingen et al. (2014) because of co-elution problems, but their patterns differ. The former was included in the "biohydrogenation" fac- 


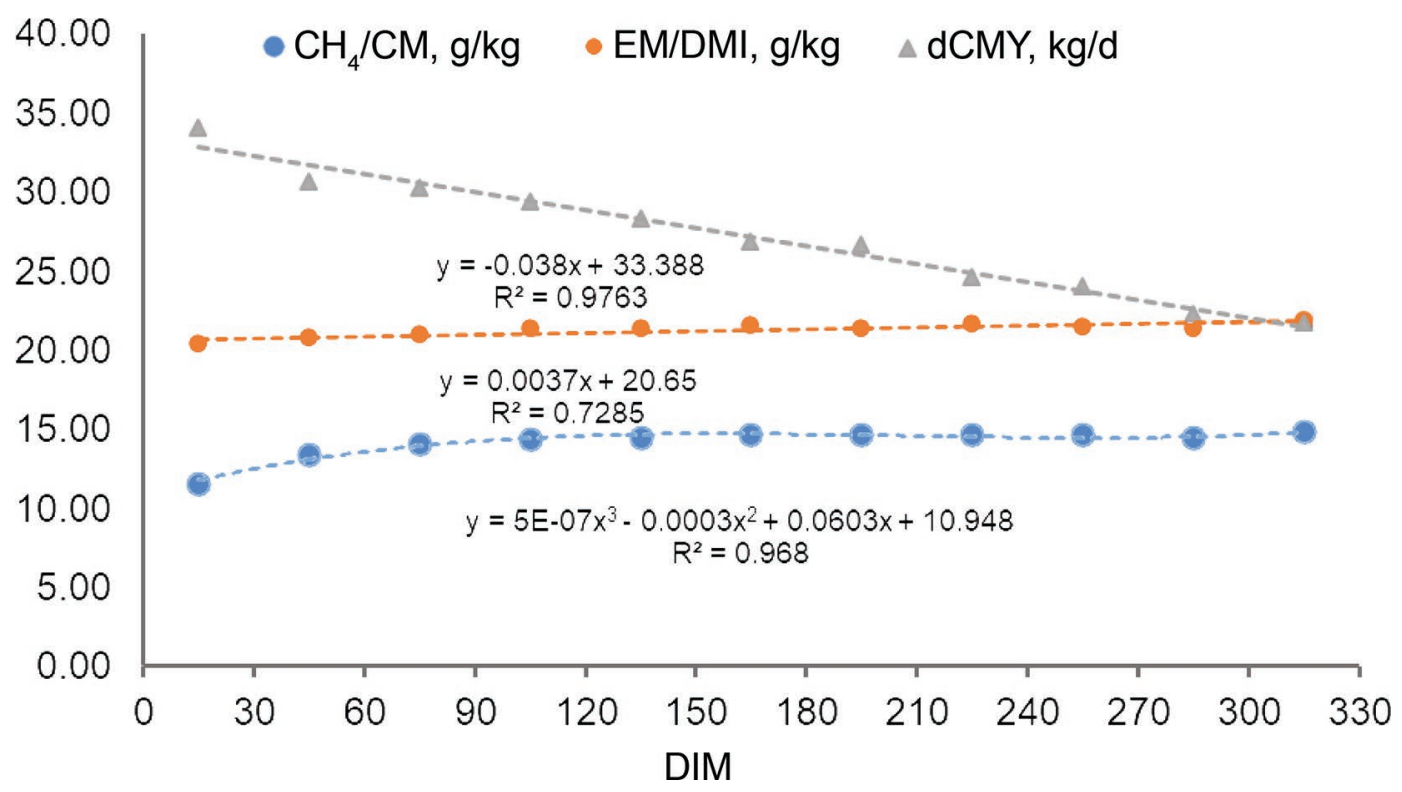

Figure 3. Effect of DIM on the milk yield (dCMY, $\mathrm{kg} / \mathrm{d}$ ) and on the predicted methane yield, per kilogram of DMI (EM/DMI, g/kg), and methane intensity, per unit of dCMY $\left(\mathrm{CH}_{4} / \mathrm{CM}, \mathrm{g} / \mathrm{kg}\right)$. Color version available online.

tor together with linoleic acid, whereas the latter was included in a "CLA" factor in multivariate analysis of Mele et al. (2016).
Comparing van Lingen et al. (2014) with the present study, the different breeds, rearing and feeding conditions, ranges of milk yield and composition, and

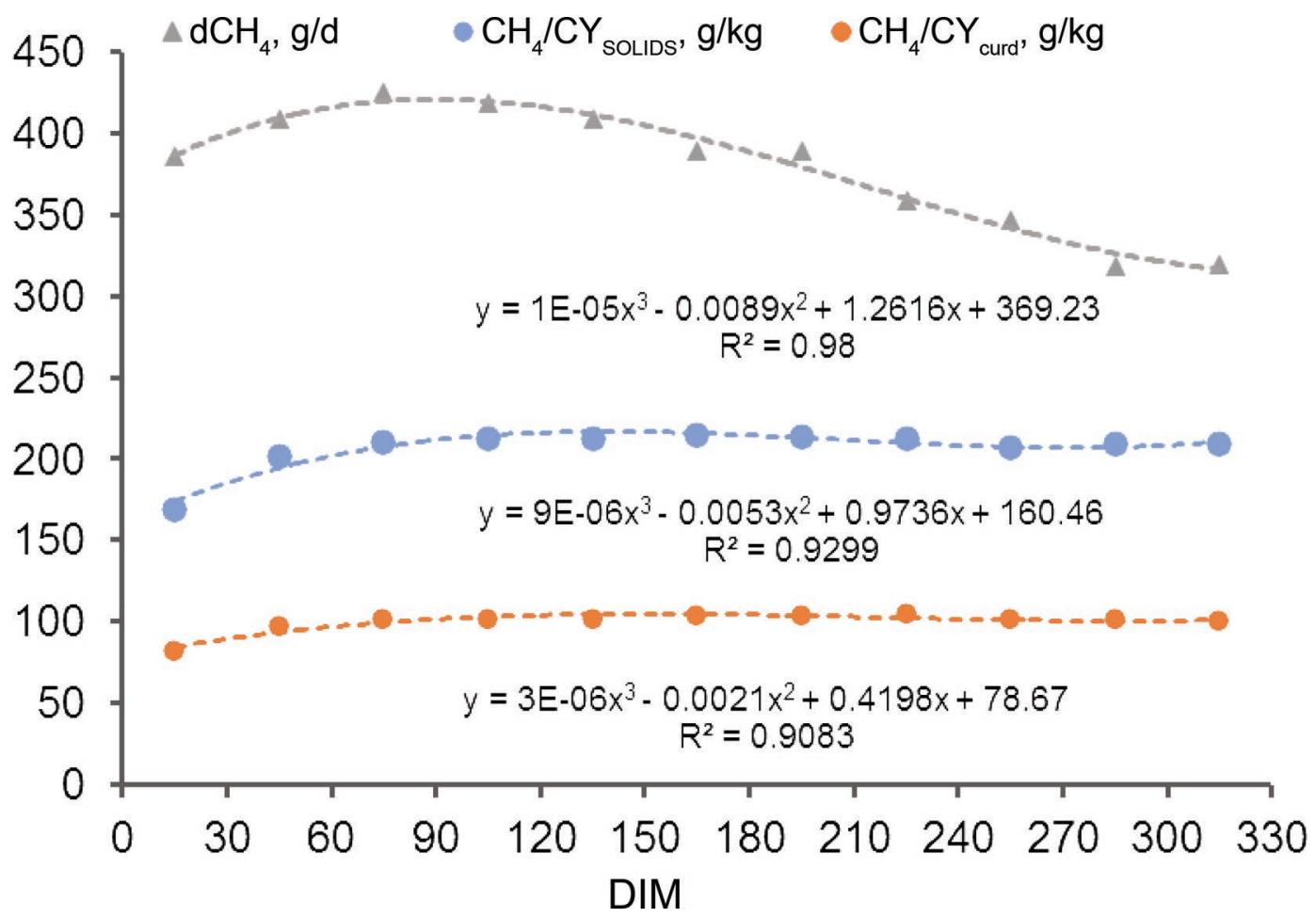

Figure 4. Effect of DIM on the predicted daily methane production per cow $\left(\mathrm{dCH}_{4}, \mathrm{~g} / \mathrm{d}\right)$ and methane intensity per unit of cheese solids $\left(\mathrm{CH}_{4} / \mathrm{CY}_{\text {SOLIDS }}, \mathrm{g} / \mathrm{kg}\right)$ and fresh cheese $\left(\mathrm{CH}_{4} / \mathrm{CY}_{\mathrm{CURD}}, \mathrm{g} / \mathrm{kg}\right)$. Color version available online. 
proportions of informative milk FA were similar so that the average estimates for both methane yield $\left(\mathrm{CH}_{4} /\right.$ DMI: 21.3 vs. $21.5 \mathrm{~g} / \mathrm{kg})$ and methane intensity $\left(\mathrm{CH}_{4} /\right.$ CM: 14.2 vs. $13.9 \mathrm{~g} / \mathrm{kg}$ ) were also similar.

We estimated $\mathrm{dCH}_{4}$ on the basis of the $\mathrm{CH}_{4} / \mathrm{CM}$ and dCMY, and we obtained an average value (357 $\mathrm{g} / \mathrm{d}$ ) that was very similar to the average value from the 8 experiments summarized by van Lingen et al. (2014). Moreover, the value is close to that found in studies based on different prediction methods, taking into account the level of milk production (Hammond et al., 2016), even though it is greater than the value simulated by Yin et al. (2015) on low-yielding Brown Swiss cows.

With the data we obtained from the cheese-making from individual cow milk, we were able to estimate the individual daily production of fresh cheese and cheese solids, and from these the methane intensity per kilogram of fresh cheese and cheese solids. The resulting $\mathrm{CH}_{4}$ values were about $100 \mathrm{~g} / \mathrm{kg}$ of fresh cheese and about $200 \mathrm{~g} / \mathrm{kg}$ of cheese solids (bearing in mind the DM content of fresh cheese was about 50\%). These are the first estimates related to cheese production that the authors are aware of.

We indirectly evaluated the coherence of the estimates obtained through prediction of the cows' dDMI $(\mathrm{kg} / \mathrm{d})$ by dividing $\mathrm{dCH}_{4}$ by $\mathrm{CH}_{4} / \mathrm{DMI}$. The result, $16.9 \pm 5.5$ $\mathrm{kg} / \mathrm{d}$ (Table 1), was consistent with the expected trends when analyzed for the effects of the major sources of variation (dairy system, parity, and DIM).

\section{Influence of Dairy System on Estimated EME}

Table 3 shows that dairy system affected 5 of the 6 informative FA used and all the EME traits obtained. Traditional dairy systems with tied cows fed mainly on hay and a few compound feeds (Sturaro et al., 2013) had greater estimated methane yield and methane intensity per unit cheese solids than modern dairy systems, but not estimated methane intensity per unit of milk and fresh cheese, and lower estimated methane production per cow per day. The greater forage:concentrate ratio and the lower daily milk yield are clearly the main reasons for these results, as EME are affected by the cow's nutritional and productive efficiencies (Knapp et al., 2014). The cellulolytic activity of rumen microbiota is expected to be greater in cows reared on traditional farms because of the greater proportion of forages in the ration (Czerkawski, 1986), and this was also reflected in the highest proportions of milk FA iso-palmitic and vaccenic acids, and the lowest proportions of linoleic acid (Dewhurst et al., 2006).

Within the modern dairy systems with free-stall housing and milking in parlors, and also with greater proportions of concentrates, the only effect of TMR versus separate feed allocation was on estimated $\mathrm{dCH}_{4}$, as indicated by differences in the average estimated $\mathrm{dMY}$ and $\mathrm{dCY}$ values. More interesting is the comparison between farms including corn silage in the TMR and those moistening it with water, which showed that corn silage-fed cows had greater estimated EME, regardless of how they are represented. In a comparison of diets formulated to meet the requirements of $\mathrm{ME}$ and protein for a range of daily milk yields, Wilkinson and Garnsworthy (2017) also predicted that $\mathrm{CH}_{4}$ emissions would increase when the source was corn silage rather than grazed pasture, grass silage, or straw. Vlaeminck et al. (2006) reported that replacing grass silage with corn silage affected the proportions of odd- and branched-chain FA in the milk, reflecting the influence on rumen microbial activity. On the other hand, Hammond et al. (2016) compared diets based on grass silage and corn silage, with or without dry roughage supplements, and found lower methane intensity per milk unit with corn silage diets, but this was also because these animals consumed more DM and produced more milk. The EME traits were higher when dry roughage was added to the corn silage-based diet but not when added to the grass silage-based diet. It is worth noting that in the current experiment, corn silage-based TMR induced much lower proportions of butyric, vaccenic, and linoleic acids in the milk fat, all of which had a negative sign in both of the EME estimation equations of van Lingen et al. (2014).

\section{Variations in Estimated EME Among Farms}

In this study, the daily production traits of cows, in terms of milk, milk corrected for composition, fresh cheese, and cheese solids, exhibited an incidence of herd/test date effect within dairy system ranging from 30 to $40 \%$ of total variance (Figure 1). In previous studies (Cipolat-Gotet et al., 2013; Bittante et al., 2013), the incidence was about $50 \%$, but dairy system was not included in the statistical model. This means that dairy system is an important source of variation in productive traits, but also that there is an important variation within dairy system among different farms. Milk composition traits and the $\% \mathrm{CY}_{\text {SOLIDS }}$ are much less variable among herds within dairy system (10 to $20 \%$ of total variance), whereas $\% \mathrm{CY}_{\mathrm{CURD}}$ is intermediate $(27 \%)$.

The incidence of the variance in herd within dairy system with respect to the 6 informative FA was, as we have seen, about half the total variance for $5 \mathrm{FA}$, but was much lower (18\%) for oleic acid (Figure 1). It is worth noting that this FA was included, with negative sign, in the latent factor "de novo FA" (Mele et al., 
2016), which had an incidence of herd variance within dairy system of $21 \%$. On the other hand, the incidence for "short-chain FA" (including butyric acid) was 49\%, for "branched-chain FA" (including iso-palmitic acid) $44 \%$, "biohydrogenation" (including iso-oleic and linoleic acids) 57\%, and "CLA" (including vaccenic acid) $42 \%$ (Mele et al., 2016). It should be borne in mind that all of the $6 \mathrm{FA}$ included in the predictive equations with the exception of oleic acid are among those with the lowest heritability and greatest incidence of herd effect (Stoop et al., 2008; Pegolo et al., 2016a), confirmation that these FA are much more dependent on farm management and feeding regimen than on the cows' genetics.

This pattern shows that all the EME traits also had very high incidences of herd effect within dairy system (50 to $60 \%$; Figure 1), with the only exception of $\mathrm{dCH}_{4}$, where the effect of herd was similar to that of production traits $(33 \%)$. It is worth noting that the 3 equations of Dijkstra et al. (2011) used at population level by van Engelen et al. (2015) yielded a herd effect accounting by 0.31 to 0.55 of the total variance of estimated methane yield.

\section{Patterns of Estimated EME According to Parity and Lactation Stage}

The effect of parity on estimated EME traits seems to be merely quantitative, as the milk produced and the feed consumed increases with the advancing age of the cow, particularly from the first to subsequent lactations, with no important qualitative aspect apparently involved.

The variations in estimated EME during lactation seem much more interesting. In particular, the 6 informative FA that van Lingen et al. (2014) proposed as predictors seem able to capture important changes in the metabolism of dairy cows, especially at the beginning of lactation. The concentration of oleic acid in milk decreases rapidly during the first trimester of lactation (Figure 2a), more likely due to the decreasing importance of FA supplied by body fat mobilization (Pegolo et al., 2016b) than to changes in diet composition. As we have seen, the variation in oleic acid is negatively related to de novo synthesis of FA by the mammary gland (Mele et al., 2016), and the increasing importance of this last source of milk FA during lactation is also shown by the linear increase in iso-oleic acid during lactation (Figure 2c).

The fact that $\mathrm{CH}_{4} / \mathrm{DMI}$ increases only slightly and almost linearly during lactation (Figure 3) is probably due to a progressive increase in the proportion of dietary structural carbohydrates during lactation with a corresponding decrease in nutrients bypassing the ru- men. This might explain why the curve representing estimates of methane production per day per cow (Figure 4) is similar in shape to the expected curve for dDMI of lactating dairy cows (Friggens et al., 1998), and differs from the curve of observed daily corrected milk yield (Figure 3). This interpretation is also supported by the fact that the $\mathrm{dDMI}$ estimated indirectly by dividing $\mathrm{dCH}_{4}$ by $\mathrm{CH}_{4} / \mathrm{DMI}$ increases slowly from an average $19.0 \mathrm{~kg} / \mathrm{d}$ in the first month of lactation to $20.4 \mathrm{~kg} / \mathrm{d}$ during the third month, then decreases to $14.8 \mathrm{~kg} / \mathrm{d}$ at the very end of lactation (data not shown).

This means that the low average estimated methane intensities at the beginning of lactation (per unit corrected milk, Figure 3; fresh cheese and cheese solids, Figure 4) may be due to the fact that part of the milk/ cheese fat is produced from the FA supplied from body tissue mobilization and not from the VFA produced in the rumen. This also means that the slight increase in estimated methane intensity with advancing lactation (after the BCS nadir has been reached) discounts the need to reconstitute the body reserves.

It is worth noting that in a large study on EME predictions based on milk infrared spectra, Vanlierde et al. (2015) found an unexpected pattern in estimated $\mathrm{dCH}_{4}$ throughout lactation, decreasing at the beginning then increasing to the end of lactation, despite using a calibration equation with a larger coefficient of determination than that of GC FA-based equation used here. These authors, to obtain a pattern reflecting the biological expectations, developed a lactation stage-dependent prediction equation, which yielded a curve very similar to that of current experiment, which was obtained without correction for lactation stage. This is further evidence that equations based on milk FA profiles are able to reflect the biological processes driving EME traits.

A final consideration regards the residual variability, which, after correcting for dairy system, herd within dairy system, parity, and lactation stage, still includes the possible contribution of the animal's genome. Even though the FA used as predictors of estimated EME traits have low heritability [3 to $10 \%$, according to Pegolo at al. (2016a)], it could be interesting to quantify the genetic parameters of EME traits estimated on the basis of milk FA profiles, as a means for evaluating the feasibility of using them for genetic improvement of the environmental impact of dairy populations (de Haas et al., 2017).

\section{CONCLUSIONS}

The present survey examined the variability and the coherence of EME traits estimated from equations based on a meta-analysis of relationships with milk FA 
profiles. This indirect method was used in a large survey at field level, and provided interesting information on the main sources of variation in the ecological footprint of the dairy sector. In particular, we confirmed the importance of dairy system for almost all EME traits, and that very traditional practices (tied animals fed on hay and some concentrates) and those modern systems using corn silage in the TMR had a slightly greater effect. Further research is needed to confirm these findings and gain a better understanding of them. We found a much greater variability among farms within dairy system for all EME traits than among dairy systems, and therefore mitigation efforts should probably concentrate first on management and feeding practices in existing farms, and subsequently on moves toward more sustainable systems. Moreover, further research is needed to validate the results in different breeds and populations, to assess the magnitude of the genetic variation of such novel traits, and to explore the potential of using the estimated EME phenotypes in breeding programs for the genetic improvement of ecological impact of dairy cow populations.

\section{ACKNOWLEDGMENTS}

The authors thank the Superbrown Consortium of Bolzano and Trento (Trento, Italy) for their support with sampling and recording, and M. Mele and G. Conte (Dipartimento di Scienze Agrarie, Alimentari, Agro-ambientali, Università di Pisa, Pisa, Italy) for their support in analyzing and discussing detailed FA profiles.

\section{REFERENCES}

Barber, M. C., R. A. Clegg, M. T. Travers, and R. G. Vernon. 1997. Lipid metabolism in the lactating mammary gland. Biochim. Biophys. Acta 1347:101-126.

Bauman, D. E., I. H. Mather, R. J. Wall, and A. L. Lock. 2006. Major advances associated with the biosynthesis of milk. J. Dairy Sci. 89:1235-1243.

Bernard, L., C. Leroux, and Y. Chilliard. 2008. Expression and nutritional regulation of lipogenic genes in the ruminant lactating mammary gland. Adv. Exp. Med. Biol. 606:67-108.

Bittante, G., C. Cipolat-Gotet, and A. Cecchinato. 2013. Genetic parameters of different measures of cheese yield and milk nutrient recovery from an individual model cheese-manufacturing process. J. Dairy Sci. 96:7966-7979.

Castro Montoya, J., A. M. Bhagwat, N. Peiren, S. De Campeneere, B. De Baets, and V. Fievez. 2011. Relationships between odd- and branched-chain fatty acid profiles in milk and calculated enteric methane proportion for lactating dairy cattle. Anim. Feed Sci. Technol. 166:596-602.

Chilliard, Y., A. Ferlay, R. M. Mansbridge, and M. Doreau. 2000. Ruminant milk fat plasticity: nutritional control of saturated, polyunsaturated, trans and conjugated fatty acids. Ann. Zootech. 49:181-205.

Chilliard, Y., C. Martin, J. Rouel, and M. Doreau. 2009. Milk fatty acids in dairy cows fed whole crude linseed, extruded linseed, or linseed oil, and their relationship with methane output. J. Dairy Sci. 92:5199-5211.

Cipolat-Gotet, C., A. Cecchinato, M. De Marchi, and G. Bittante. 2013. Factors affecting variation of different measures of cheese yield and milk nutrient recovery from an individual model cheesemanufacturing process. J. Dairy Sci. 96:7952-7965.

Crompton, L. A., J. A. N. Mills, K. E. Kliem, and C. K. Reynolds. 2011. Effect of milled rapeseed on methane emissions and milk quality in lactating dairy cows. Adv. Anim. Biosci. 2:75.

Crompton, L. A., J. A. N. Mills, and C. K. Reynolds. 2010. Effect of feeding frequency and replacing calcium salts of palm oil with crushed rapeseed or coconut oil on methane emissions in lactating dairy cows. Proc. Nutr. Soc. 69:E329.

CVB. 2008. CVB Table Booklet Feeding of Ruminants. CVB series no. 43. Centraal Veevoederbureau, Lelystad, the Netherlands.

Czerkawski, J. W. 1986. An Introduction to Rumen Studies. Pergamon Press Ltd., Oxford, UK.

de Haas, Y., M. Pszczola, H. Soyeurt, E. Wall, and J. Lassen. 2017. Invited review: Phenotypes to genetically reduce greenhouse gas emissions in dairying. J. Dairy Sci. 100:855-870.

de Haas, Y., J. J. Windig, M. P. L. Calus, J. Dijkstra, M. de Haan, A. Bannink, and R. F. Veerkamp. 2011. Genetic parameters for predicted methane production and potential for reducing enteric emissions through genomic selection. J. Dairy Sci. 94:6122-6134.

Dehareng, F., C. Delfosse, E. Froidmont, and H. Soyeurt. 2012. Potential use of milk mid-infrared spectra to predict individual methane emission of dairy cows. Animal 6:1694-1701.

Demeyer, D. I., and C. J. van Nevel. 1975. Methanogenesis, an integrated part of carbohydrate fermentation and its control. Pages 366-382 in Digestion and Metabolism in the Ruminant. I. W. McDonald and A. C. I. Warner, ed. University of New England, Armidale, Australia.

Dewhurst, R. J., K. J. Shingfield, M. R. F. Lee, and N. D. Scollan. 2006. Increasing the concentrations of beneficial polyunsaturated fatty acids in milk produced by dairy cows in high-forage systems. Anim. Feed Sci. Technol. 131:168-206.

Dijkstra, J., S. van Gastelen, E. C. Antunes-Fernandes, D. Warner, B. Hatew, G. Klop, S. C. Podesta, H. J. van Lingen, K. A. Hettinga, and A. Bannink. 2016. Relationships between milk fatty acid profiles and enteric methane production in dairy cattle fed grass- or grass silage-based diets. Anim. Prod. Sci. 56:541-548.

Dijkstra, J., S. M. van Zijderveld, J. A. Apajalahti, A. Bannink, W. J. J. Gerrits, J. R. Newbold, H. B. Perdok, and H. Berends. 2011. Relationships between methane production and milk fatty acid profiles in dairy cattle. Anim. Feed Sci. Technol. 166-167:590-595.

Doreau, M., and A. Ferlay. 1993. Digestion and utilization of fatty acids by ruminants. Anim. Feed Sci. Technol. 45:379-396.

Feng, S., A. L. Lock, and P. C. Garnsworthy. 2004. A rapid lipid separation method for determining fatty acid composition of milk. J. Dairy Sci. 87:3785-3788.

Friggens, N. C., G. C. Emmans, I. Kyriazakis, J. D. Oldham, and M. Lewis. 1998. Feed intake relative to stage of lactation for dairy cows consuming total mixed diets with a high or a low ratio of concentrate to forage. J. Dairy Sci. 81:2228-2239.

Hammond, K. J., A. K. Jones, D. J. Humphries, L. A. Crompton, and C. K. Reynolds. 2016. Effects of diet forage source and neutral detergent fiber content on milk production of dairy cattle and methane emissions determined using GreenFeed and respiration chamber techniques. J. Dairy Sci. 99:7904-7917.

Knapp, J. R., G. L. Laur, P. A. Vadas, W. P. Weiss, and J. M. Tricarico. 2014. Invited review: Enteric methane in dairy cattle production: Quantifying the opportunities and impact of reducing emissions. J. Dairy Sci. 97:3231-3261.

Maurice-Van Eijndhoven, M. H. T., H. Bovenhuis, H. Soyeurt, and M. P. L. Calus. 2013. Differences in milk fat composition predicted by mid-infrared spectrometry among dairy cattle breeds in the Netherlands. J. Dairy Sci. 96:2570-2582.

Mele, M., N. P. P. Macciotta, A. Cecchinato, G. Conte, S. Schiavon, and G. Bittante. 2016. Multivariate factor analysis of detailed milk fatty acid profile: Effects of dairy system, feeding, herd, parity, and stage of lactation. J. Dairy Sci. 99:9820-9833. 
Mele, M., A. Serra, A. Buccioni, G. Conte, A. Pollicardo, and P. Secchiari. 2008. Effect of soybean oil supplementation on milk fatty acid composition from Saanen goats fed diets with different forage: concentrate ratios. Ital. J. Anim. Sci. 7:297-311.

Mohammed, R., S. M. McGinn, and K. A. Beauchemin. 2011. Prediction of enteric methane output from milk fatty acid concentrations and rumen fermentation parameters in dairy cows fed sunflower, flax, or canola seeds. J. Dairy Sci. 94:6057-6068.

Morvay, Y., A. Bannink, J. France, E. Kebreab, and J. Dijkstra. 2011. Evaluation of models to predict the stoichiometry of volatile fatty acid profiles in rumen fluid of lactating Holstein cows. J. Dairy Sci. 94:3063-3080.

Negussie, E., Y. de Haas, F. Dehareng, R. J. Dewhurst, J. Dijkstra, N. Gengler, D. P. Morgavi, H. Soyeurt, S. van Gastelen, T. Yan, and F. Biscarini. 2017. Invited review: Large-scale indirect measurements for enteric methane emissions in dairy cattle: A review of proxies and their potential for use in management and breeding decisions. J. Dairy Sci. 100:2433-2453.

Pegolo, S., A. Cecchinato, J. Casellas, G. Conte, M. Mele, S. Schiavon, and G. Bittante. 2016a. Genetic and environmental relationships of detailed milk fatty acids profile determined by gas chromatography in Brown Swiss cows. J. Dairy Sci. 99:1315-1330.

Pegolo, S., A. Cecchinato, M. Mele, G. Conte, S. Schiavon, and G. Bittante. 2016b. Effects of candidate gene polymorphisms on the detailed fatty acids profile determined by gas chromatography in bovine milk. J. Dairy Sci. 99:4558-4573.

Pegolo, S., C. Dadousis, N. Mach, Y. Ramayo-Caldas, M. Mele, G. Conte, S. Schiavon, G. Bittante, and A. Cecchinato. 2017. SNP co-association and network analyses identify E2F3, KDM5A and BACH2 as key regulators of the bovine milk fatty acid profile. Sci. Rep. 7:17317. https://doi.org/10.1038/s41598-017-17434-7.

Pitesky, M. E., K. R. Stackhause, and F. M. Mitloehner. 2009 Clearing the air: Livestock's contribution to climate change. Advances in Agronomy 103:1-40. https://doi.org/10.1016/S0065 -2113(09)03001-6.

Poulsen, N. A., F. Gustavsson, M. Glantz, M. Paulsson, L. B. Larsen, and M. K. Larsen. 2012. The influence of feed and herd on fatty acid composition in 3 dairy breeds (Danish Holstein, Danish Jersey, and Swedish Red). J. Dairy Sci. 95:6362-6371.

Reynolds, C. K., D. J. Humphries, P. Kirton, L. A. Crompton, J. A. N. Mills, and D. I. Givens. 2010. Methane production by lactating dairy cows fed diets containing allicin, glycerol or naked oats. Page 120 in Proc. 4th Int. Greenhouse Gases Anim. Agric. Conf., Banff, Canada.

Reynolds, C. K., D. J. Humphries, K. M. Livingstone, K. E. Kliem, and D. I. Givens. 2012. Effect of forage type and an extruded linseed supplement on methane production by lactating dairy cows. Adv. Anim. Biosci. 3:9.

Rico, D. E., P. Y. Chouinard, F. Hassanat, C. Benchaar, and R. Gervais. 2016. Prediction of enteric methane emissions from Holstein dairy cows fed various forage sources. Animal 10:203-211. https:// doi.org/10.1017/S1751731115001949.

Shingfield, K. J., L. Bernard, C. Leroux, and Y. Chilliard. 2010. Role of trans fatty acids in the nutritional regulation of mammary lipogenesis in ruminants. Animal 4:1140-1166.

Shingfield, K. J., M. Bonnet, and N. D. Scollan. 2013. Recent developments in altering the fatty acid composition of ruminant-derived foods. Animal 7:132-162.
Stoop, W. M., J. A. van Arendonk, J. M. Heck, H. J. van Valenberg, and $\mathrm{H}$. Bovenhuis. 2008. Genetic parameters for major milk fatty acids and milk production traits of Dutch Holstein-Friesians. J. Dairy Sci. 91:385-394.

Sturaro, E., E. Marchiori, G. Cocca, M. Penasa, M. Ramanzin, and G. Bittante. 2013. Dairy systems in mountainous areas: Farm animal biodiversity, milk production and destination, and land use. Livest. Sci. 158:157-168.

van Engelen, S., H. Bovenhuis, J. Dijkstra, J. A. M. van Arendonk, and M. H. P. W. Visker. 2015. Short communication: Genetic study of methane production predicted from milk fat composition in dairy cows. J. Dairy Sci. 98:8223-8226.

van Gastelen, S., E. C. Antunes Fernandes, K. A. Hettinga, G. Klop, S. J. J. Alferink, and J. Dijkstra. 2014. Replacing grass silage with maize silage affects rumen fermentation characteristics and enteric methane production in dairy cattle. In Proc. 39th Anim. Nutr. Res. Forum, Utrecht, the Netherlands. Universiteit Utrecht, Utrecht, the Netherlands.

van Gastelen, S., and J. Dijkstra. 2016. Prediction of methane emission from lactating dairy cows using milk fatty acids and mid-infrared spectroscopy. Mini review. J. Sci. Food Agric. 96:3963-3968. van Lingen, H. J., L. A. Crompton, W. H. Hendriks, C. K. Reynolds, and J. Dijkstra. 2014. Meta-analysis of relationships between enteric methane yield and milk fatty acid profile in dairy cattle. J. Dairy Sci. 97:7115-7132.

van Zijderveld, S. M., J. Dijkstra, H. B. Perdok, J. R. Newbold, and W. J. J. Gerrits. 2011a. Dietary inclusion of diallyl disulfide, yucca powder, calcium fumarate, an extruded linseed product, or medium-chain fatty acids does not affect methane production in lactating dairy cows. J. Dairy Sci. 94:3094-3104.

van Zijderveld, S. M., B. Fonken, J. Dijkstra, W. J. J. Gerrits, H. B. Perdok, W. Fokkink, and J. R. Newbold. 2011b. Effects of a combination of feed additives on methane production, diet digestibility, and animal performance in lactating dairy cows. J. Dairy Sci. 94:1445-1454.

Vanlierde, A., M.-L. Vanrobays, F. Dehareng, E. Froidmont, H. Soyeurt, S. McParland, and E. Lewis. 2015. Hot topic: Innovative lactation-stage-dependent prediction of methane emissions from milk mid-infrared spectra. J. Dairy Sci. 98:5740-5747.

Vlaeminck, B., V. Fievez, A. R. J. Cabrita, A. J. M. Fonseca, and R J. Dewhurst. 2006. Factors affecting odd- and branched-chain fatty acids in milk: A review. Anim. Feed Sci. Technol. 131:389-417.

Wilkinson, J. M., and P. C. Garnsworthy. 2017. Dietary options to reduce the environmental impact of milk production. J. Agric. Sci. 155:334-347.

Williams, S. R. O., B. Williams, P. J. Moate, M. H. Deighton, M. C. Hannah, and W. J. Wales. 2014. Methane emissions of dairy cows cannot be predicted by the concentrations of $\mathrm{C} 8: 0$ and total $\mathrm{C} 18$ fatty acids in milk. Anim. Prod. Sci. 54:1757-1761. https://doi .org/10.1071/AN14292.

Yin, T., T. Pinent, K. Brügemann, H. Simianer, and S. König. 2015. Simulation, prediction, and genetic analyses of daily methane emissions in dairy cattle. J. Dairy Sci. 98:5748-5762. 